\title{
IMPLEMENTASI PROGRAM UJI KOMPETENSI TEKNOLOGI INFORMASI DAN KOMUNIKASI (TIK) DI SEKOLAH MENENGAH ATAS NEGERI 1 IMOGIRI
}

\author{
IMPLEMENTATION OF INFORMATION AND COMMUNICATION (ICT) \\ COMPETENCE TEST PROGRAM IN MEDIUM STATE 1 IMOGIRI
}

\author{
Riski Anggi Safitri \\ Filsafat dan Sosiologi Pendidikan, Kebijakan Pendidikan FIP UNY \\ riski.anggi2016@student.uny.ac.id
}

\begin{abstract}
Abstrak
Penelitian ini bertujuan untuk mendeskripsikan implementasi program uji kompetensi TIK. Deskripsi meliputi latar belakang pelaksanaan program, implementasi program, serta faktor pendukung dan penghambat implementasi program uji kompetensi TIK di SMA Negeri 1 Imogiri. Penelitian ini menggunakan pendekatan kualitatif dengan metode deskriptif. Teknik pengumpulan data yang digunakan adalah observasi, wawancara dan studi dokumen. Teknik analisis data yang digunakan yakni pengumpulan data, kondensasi data, penyajian data, penarikan kesimpulan. Hasil dari penelitian ini: (1) Latarbelakang SMA Negeri 1 Imogiri melaksanakan program uji kompetensi TIK, dikarenakanlulusan yang melanjutkan ke jenjang perguruan tinggi masih sangat rendah sehingga sekolah memberikan keterampilan tambahan sebagai bekal memasuki dunia kerja. (2) Implementasi program uji kompetensi TIK di SMA Negeri 1 Imogiri: a) Komunikasi dilakukan dengan mengadakan rapat dan sosialisasi kepada orang tua siswa dan juga siswa, b) Sumberdaya didukung dengan ketersediaan SDM yaitu ada penanggung jawab, pelatih dan ketua serta ada kerjasama dengan berbagai lembaga pelatihan komputer, dana Bantuan Operasional Sekolah (BOS) dan dana Bantuan Operasional Sekolah Daerah (BOSDA) dan fasilitas didukung dengan laboratorium komputer yang memadai, c) Disposisi termuat dalam visi misi dan tujuan sekolah serta tercermin dari kecakapan agen pelaksana, d) Struktur birokrasi, Kepala sekolah sebagai penanggung jawab dan pelatih yang memimpin latihan. (3) Faktor pendukung yaitu fasilitas yang memadai, dukungan penuh sekolah, dana operasional dari pemerintah, kerjasama dengan pihak luar. Sedangkan faktor penghambat yaitu waktu pelatihan yang kurang, latarbelakang siswa yang berbeda.
\end{abstract}

Kata kunci: Implementasi, Program Uji Kompetensi TIK, SMA Negeri 1 Imogiri

\begin{abstract}
This study aims to describe the implementation of the ICT competency test program. The description includes the background of the implementation of the program, the implementation of the program, as well as the supporting and inhibiting factors for the implementation of the ICT competency test program at SMA 1 Imogiri. This research uses a qualitative approach with descriptive methods. Data collection techniques used were observation, interviews and document studies. Data analysis techniques used are data collection, data condensation, data presentation, drawing conclusions. The results of this study: (1) The background of Imogiri State High School 1 is implementing an ICT competency test program, because graduates who continue to tertiary level are still very low so that schools provide additional skills as a provision to enter the workforce. (2) The implementation of the ICT competency test program at Imogiri 1 High School: a) Communication is carried out by holding meetings and socializing to parents of students and also students, $b$ ) Resources are supported by the availability of human resources namely there is a person in charge, trainers and chairs and there is collaboration with various computer training institutions, School Operational Assistance funds (BOS) and Regional School Operational Assistance funds (BOSDA) and facilities supported with adequate computer laboratories, c) Disposition contained in the vision and mission of the school and reflected in the capabilities of the implementing agency, d) bureaucratic structure The principal is the person in charge and the trainer who leads the training. (3) Supporting factors are adequate facilities, full school support, operational funds from the government, collaboration with outside parties. While the inhibiting factor is lack of training time, different student backgrounds.
\end{abstract}

Keywords: Implementation, ICT Competency Test Program, Imogiri State High School 1 


\section{PENDAHULUAN}

Dalam Undang-undang Republik Indonesia No. 20 Tahun 2003 tentang Sistem Pendidikan Nasional dijelaskan bahwa : "Tujuan pendidikan menengah atas (SMA) adalah mengutamakan penyiapan siswa untuk melanjutkan pendidikan pada jenjang pendidikan tinggi". Namun pada kenyataanya saat ini tidak semua lulusan SMA dapat melanjutkan pendidikan tinggi selain itu juga Angka Partisipasi Kasar (APK) Pendidikan Tinggi di Indonesia masih tertinggal dibandingkan dengan beberapa negara ASEAN lainya. Angka Partisipasi Kasar (APK) Pendidikan Tinggi di Indonesia baru mencapai $30 \%$ sedangkan Malayasia 38\% dan Singapura

78\%. Bersadarkan data Kemenristekdikti 2018, APK Pendidikan Tinggi Indonesia tahun 2017 menunjukan angka 30\% dan 2018 menunjukkan angka

$$
\text { 32,55 \% }
$$

(Kemenristekdikti, 2018).

Faktor rendahnya APK Pendidikan Tinggi di Indonesia ini antara lain : Pertama, Prioritas pembangunan pendidikan Indonesia baru pada usaha wajib belajar pendidikan dasar

9 tahun menuju wajib belajar 12 tahun, sehingga APK pendidikan dasar lebih besar yakni mencapai 95\%. Kedua, kurang meratanya kualitas pendidikan tinggi di Indonesia. Hal ini antara lain bisa dilihat dari data perguruan tinggi, baik PTN dan PTS yang telah terakreditasi dengan nilai A Saat ini, tercatat ada 27 PTS di bawah binaan Kemenristekdikti sudah mendapatkan nilai akreditasi A, akan tetapi PTS yang terakreditasi A masih terkonsentrasi di Pulau Jawa. Kesenjangan kualitas ini juga memberi pengaruh pada raihan APK PT yang dicapai. Ketiga, Pendidikan tinggi di Indonesia masih bercirikan akademik. Artinya layanan pendidikan yang diberikan cenderung terbatas pada pendidikan akademik jenjang S1, S2, atau S3. Perguruan Tinggi di Indonesia masih kurang membuka program profesi dan pendidikan vokasi dari jenjang diploma 1 sampai dengan diploma 4 atau sarjana terapan. Padahal pendidikan profesi dan pendidikan vokasi pun, lulusannya sangat dibutuhkan untuk memenuhi angkatan kerja di berbagai sektor industri dan sektor jasa (Pusat Teknologi Informasi Komunita Widyatama, 2019). Kondisi ekonomi keluarga juga menjadi faktor yang menyebabkan lulusan SMA tidak melanjutkan pendidikan tinggi dan memilih untuk bekerja. Seperti Riset yang dilakukan Haruka Evolusi Digital Utama (HarukaEDU) di 2018 menyebutkan, 66\% responden di antaranya urung kuliah karena mengaku terkendala biaya (Citra larasati, 2018).

Upaya yang dapat dilakukan untuk merespon permasalahan tersebut adalah dengan memberikan tambahan keterampilan bagi peserta didik SMA. Pemerintah telah mengupayakan hal tersebut melalui pendidikan kecakapan hidup. Pendidikan kecakapan hidup merupakan salah satu alternatif sebagai upaya mempersiapkan peserta didik agar memiliki sikap dan kecakapan hidup sebagai bekal bagi kehidupannya kelak melalui sebuah kegiatan pembelajaran yang aktif, kreatif dan menyenangkan. Berdasar Undang-undang No. 20 Tahun 2003 tentang Sistem

Pendidikan Nasional pasal 26 ayat 3 menjelaskan bahwa: "Pendidikan kecakapan hidup adalah pendidikan yang memberikan kecakapan personal, kecakapan sosial, kecakapan intelektual dan kecakapan vokasional untuk bekerja atau usaha mandiri".

\section{Pendidikan kecakapan hidup juga dirumuskan dalam Peraturan Pemerintah No.}

19 Tahun 2005 tentang Standar Nasional Pendidikan. Pada pasal 13 ayat 1-4, termuat diktum pendidikan kecakapan hidup sebagai berikut : Kurikulum untuk SMP/MTs/SMPLB atau bentuk lain yang sederajat, SMA/MA/SMALB atau bentuk lain yang sederajat, SMK/MAK atau bentuk lain yang sederajat dapat memasukkan pendidikan kecakapan hidup. Pendidikan kecakapan hidup pada jenjang TK/SD/SMP lebih menekankan kepada kecakapan hidup umum (generic life skill), yaitu mencakup aspek kecakapan personal (personal skill) dan 
kecakapan sosial (social skill). Sedangkan pada tingkat SMA dapat menggunakan kecakapan hidup vokasional yang berkaitan dengan bidang pekerjaan tertentu yang terdapat di masyarakat atau lingkungan peserta didik, misalnya merangkai dan mengoperasikan computer.

Dalam undang-undang Republik Indonesia No. 20 Tahun 2003 tentang Sistem Pendidikan Nasional juga tersirat bahwa pendidikan nasional mempunyai visi terwujudnya sistem pendidikan sebagai pranata sosial yang kuat dan berwibawa untuk memberdayakan semua warga negara Indonesia berkembang menjadi manusia yang berkualitas sehingga mampu dan proaktif menjawab tantangan zaman yang selalu berubah. Sejalan dengan visi tersebut peserta didik SMA diharapkan mampu mengikuti perkembangan teknologi informasi dan komunikasi (TIK) khususnya teknologi internet yang dewasa ini begitu pesat membawa dampak pada pola dan ragam kompetensi yang harus dimiliki oleh peserta didik sekolah menengah. Peserta didik SMA diharapkan mampu mengoperasikan dan memanfaatkan perangkat TIK (baik perangkat keras maupun perangkat lunak). Oleh karena itu uji kompetensi di bidang TIK bagi peserta didik SMA dapat dilakukan untuk mengetahui apakah mereka dapat melakukan pekerjaan terkait dengan TIK pada level tertentu.

Mengenai uji kompetensi dinyatakan dalam PP 19 Tahun 2005 pasal 89 ayat 1 bahwa pencapaian kompetensi akhir peserta didik dinyatakan dalam dokumen ijazah dan/atau sertifikat kompetensi. Selanjutnya pasal 89 ayat 5 juga menyatakan bahwa sertifikat kompetensi yang dimaksud dalam ayat 1 diterbitkan oleh satuan pendidikan yang terakreditasi atau lembaga sertifikasi mandiri yang dibentuk organisasi profesi yang diakui pemerintah sebagai tanda bahwa peserta didik yang bersangkutan telah lulus uji kompetensi. Selain landasan hukum yang telah dijabarkan tersebut, uji kompetensi juga mengacu pada Peraturan Menteri (Permen) Nomor 22 tahun 2006 tentang Standar Isi. Tertuang pada Pasal 1 ayat 1 dijelaskan bahwa Standar isi mencakup lingkungan materi minimal dan tingkat kompetensi minimal untuk mencapai kompetensi lulusan minimal pada jenjang dan jenis pendidikan tertentu.

Fauzi Eka Putra (2017: 35) mengatakan bahwa kompetensi secara sederhana dilihat sebagai kemampuan seseorang yang di dalamnya terdapat keterampilan, pengetahuan dan sikap dalam melakukan kegiatan atau pekerjaan tertentu sesuai dengan standar yang ada. Berdasarkan Pedoman BNSP 304-2008 uji kompetensi adalah proses penilaian baik teknis maupun non teknis melalui pengumpulan bukti yang relevan untuk menentukan apakah seseorang kompeten atau belum kompeten pada suatu unit kompetensi atau kualifikasi tertentu. Sehingga uji kompetensi merupakan pernyataan yang menguraikan hal-hal yang perlu dilakukan dalam proses penilaian atau pengukuran kemampuan seseorang mulai dari keterampilan, pengetahuan dan sikap yang harus dilakukan saat bekerja serta penerapannya, sesuai dengan persyaratan yang ditetapkan oleh tempat kerja (industri). SMA Negeri 1 Imogiri merupakan salah satu sekolah menengah atas yang membekali lulusanya dengan keterampilan kecakapan hidup melalui berbagai program. Salah satu nya dilakukan melalui penyelenggaraan uji kompetensi TIK. Pelaksanaan program uji kompetensi TIK di sekolah tersebut masih mengalami kendala. Salah satunya adalah waktu latihan yang dirasa masih telalu singkat. Pelatihan dilakukan hanya setelah pulang sekolah dan terhitung hanya sekali dalam satu minggu. Pelaksanaan uji kompetensi ini didukung oleh Lembaga Sertifikasi Kompetensi (LSK) TIK di bawah Pendidikan Non Formal Kemendikbud RI. Lembaga Sertifikasi Kompetensi TIK adalah Lembaga Sertifikasi Kompetensi tingkat Nasional yang ditetapkan oleh Kemdikbud untuk menyelenggarakan Sertifikasi Kompetensi di bidang komputer di seluruh Indonesia berdasarkan Surat Ketetapan Kemdikbud:SK.KEP/152/E/KK/2009.

Berdasarkan data nomor peserta uji kompetensi, hingga saat ini telah lebih dari 2000 siswa dan masyarakat umum telah mengikuti Uji Kompetensi TIK di SMA Negeri 1 Imogiri, dengan persentase kelulusan sekitar $80 \%$. Hingga saat ini 
SMA Negeri 1 Imogiri 9 merupakan satusatunya sekolah menengah non kejuruan di Yogyakarta bahkan di Indonesia yang memiliki lembaga kursus dan tempat uji kompetensi.

Charles O. Jones dalam Arif Rohman (2012: 106) mengatakan implementasi adalah suatu aktivitas, yang dimaksudkan untuk mengoperasikan sebuah program. Sedangkan program menurut Suharsimi Arikunto dan Cepi Safaruddin Abdul Jabar (2004: 3) adalah suatu unit atau kesatuan kegiatan yang merupakan realisasi atau implementasi dari suatu kebijakan. Sudjana (2004: 1) juga berpendapat bahwa program dapat diartikan sebagai kegiatan yang dilakukan oleh perorangan, kelompok, dan/organisasi (lembaga) yang memuat komponen-komponen program. Sehingga dapat dikatakan bahwa implementasi program yaitu suatu proses kegiatan terencana yang dilaksanakan secara berkesinambungan.

\section{METODE PENELITIAN Jenis Penelitian}

Penelitian ini menggunakan pendekatan penelitian kualitatif deskriptif.

\section{Tempat dan Waktu Penelitian}

Penelitian ini dilaksanakan di SMA Negeri 1 Imogiri pada Desember 2019 Maret 2020.

\section{Subyek/Obyek Penelitian}

Subjek penelitian ini adalah pihakpihak yang dijadikan narasumber dalam penelitian, yaitu Kepala Sekolah, Ketua tim program, Pelatih atau Guru, dan siswa kelas XI. Sementara obyek dalam penelitian ini adalah implementasi program uji kompetensi TIK di Sekolah Menengah Atas Negeri 1 Imogiri.

\section{Teknik Pengumpulan Data}

Teknik pengumpulan data yang digunakan adalah observasi, wawancara dan studi dokumen. Observasi yang digunakan dalam penelitian ini yaitu observasi nonpartisipan tak terstruktur .Observasi dilakukan terhadap kegiatan program uji kompetensi TIK di Sekolah Menengah Atas Negeri 1 Imogiri. Peneliti datang ketempat penelitian tidak turut serta dalam kegiatan namun hanya melakukan pengamatan terhadap kegiatan yang dilaksanakan. Dalam penelitian ini, peneliti menggunakan dua jenis wawancara yaitu wawancara terstruktur dan wawancara tidak terstruktur. Sebelumnya peneliti telah merancang pedoman wawancara secara lengkap agar informasi yang dibutuhkan dapat terpenuhi serta jalannya wawancara tetap terarah sesuai dengan yang diinginkan, tetapi apabila ditemukan pertanyaan yang dapat di kaji lebih dalam dan berhubungan dengan fokus penelitian maka peneliti akan melakukan pertanyaan tambahan terkait hal tersebut. Wawancara dilakukan kepada Kepala Sekolah, Guru, dan siswa.Pengambilan dokumen dalam penelitian ini berupa catatan peristiwa yaitu profil Sekolah Menengah Atas Negeri 1 Imogiri, dokumen mengenai program uji kompetensi, dan foto-foto yang terkait.

\section{Teknik Analisis Data}

Teknik analisis data dalam penelitian ini menggunakan model analisis data kualitatif dari Miles, Huberman dan Saldana (2014:12-14). Aktivitas analisisnya meliputi : kondensasi data, penyajian data dan penarikan kesimpulan.

\section{Teknik Keabsahan Data}

Dalam penelitian ini keabsahan data dilakukan dengan cara triangulasi data sumber dan teknik. Triangulasi sumber dilakukan dengan menguji keterangan hasil wawancara dengan menggunakan hasil wawancara dari subyek yang lain, sedangkan triangulasi teknik dilakukan dengan menguji hasil wawancara dengan hasil observasi atau telaah dokumen.

\section{HASIL DAN PEMBAHASAN}

1. Latar Belakang Pelaksanaan Program Uji Kompetensi TIK di SMA Negeri 1 Imogiri

Program uji kompetensi TIK ini berangkat dari permasalahan yang terjadi di SMA Negeri

1 Imogiri yakni masih rendahnya presentase lulusan yang melanjutkan pendidikan tinggi, padahal telah dijelaskan dalam UU No. 20 tahun 2003 tentang 81 
Sistem Pendidikan Nasional bahwa tujuan pendidikan menengah atas (SMA) adalah penyiapan siswa untuk melanjutkan pendidikan pada jejang pendidikan tinggi. Sehingga sekolah perlu memberikan tambahan keterampilan bagi siswanya sebagai bekal bagi kehidupannya kelak, misalnya pada saat memasuki dunia kerja.

Anwar (2006: 36) mengatakan bahwa pada jejang pendidikan menengah umum (SMU/MA) selain penekanan kecakapan akademik (AS) dan GLS perlunya ditambahkan dengan kecakapan vokasional/vocational skills (VS). Dalam kaitan ini di SMA Negeri 1 Imogiri telah menyelenggarakan program uji kompetensi TIK tersebut. Program ini dilaksanakan kepada siswa SMA Negeri 1 Imogiri khususnya kelas XI yang bertujuan untuk memberikan bekal keterampilan tambahan yang dapat digunakan pada saat memasuki dunia kerja, keterampilan yang dimaksud adalah keterampilan dalam bidang TIK.

Merujuk dari Peraturan Menteri Pendidikan Nasional Nomor 70 Tahun 2008 menjelaskan bahwa Penguji pada uji kompetensi adalah tenaga pendidik yang telah memenuhi standar kualifikasi dan kompetensi penguji pada kursus dan pelatihan berdasarkan penugasan dari Lembaga Sertifikasi. Dalam pelaksanaan uji kompetensi TIK SMA Negeri 1 Imogiri pelatih yang ditugaskan dalam kegiatan latihan tersebut merupakan guru yang telah memiliki sertifikat kompetensi sebelumnya.

\section{Implementasi Program Uji Kompetensi} TIK di SMA Negeri 1 Imogiri

Implementasi program merupakan salah satu tahap penting dalam suatu proses kebijakan. Program perlu diimplementasikan agar memiliki dampak dan tujuan yang hendak dicapai. Implementasi program uji kompetensi TIK di SMA Negeri 1 Imogiri dalam penelitian ini menggunakan konsep implementasi Edward III, Adapun aspek implemenatasi yang diteliti antara lain : komunikasi, sumberdaya, disposisi serta struktur birokrasi.

a. Komunikasi

Komunikasi merupakan aspek yang penting dalam mensukseskan impelemantasi suatu program. Komunikasi dilakukan oleh SMA Negeri 1 Imogiri kepada pelaksana, orang tua siswa, dan juga siswa.

1) Komunikasi dengan Pelaksana Komunikasi dengan pelaksana program

dilakukan sekolah dengan melakukan sosialisasi kepada staf manajemen, tenaga pendidik, tenaga kependidikan, dan para stakeholder terkait program uji kompetensi TIK dengan mengadakan rapat.

2) Komunikasi dengan Orang tua siswa dan siswa

Komunikasi dengan orang tua dilakukan oleh sekolah terkait dengan program uji kompetensi TIK, disampaikan melalui kegiatan sosialisasi secara langsung saat penerimaan peserta didik baru (PPDB) serta menjelang tahun ajaran baru juga pada saat pada saat rapat komite atau pertemuan orang tua wali siswa. Komunikasi juga disampaikan kepada siswa melalui sosialisasi program pada saat upacara bendera yang dilakukan disekolah.

Selain berkomunikasi secara langsung, sekolah juga memanfaatkan media cetak maupun media social untuk mengkomunikasikan program uji kompetensi TIK, yaitu dengan menggunakan brosur dan web sekolah.

b. Sumber Daya

\section{1) Sumber Daya Manusia}

Sumber daya manusia, dalam melaksanakan program uji kompetensi TIK adalah seluruh stakeholder program uji kompetensi TIK. Program uji kompetensi juga didukung dengan guru yang berkompeten untuk melaksanakan program tersebut. Pihak SMA Negeri 1 Imogiri juga bekerja sama dengan beberapa lembaga seperti Lembaga Sertifikasi Kompetensi (LSK), Dinas Pendidikan khusunya pendidikan non formal. Lembaga Kursus dan Pelatihan (LKP), Balai Latihan Kerja (BLK).

2) Sumber Pendanaan

Pendanaan dalam melaksanakan program uji kompetensi TIK di SMA Negeri 1 Imogri, bersumber dari Pemerintah melalui Bantuan Operasional Sekolah (BOS), Bantuan Operasional Sekolah Daerah (BOSDA) dan juga dana 
kerjasama yang berasal dari kerjasama sekolah dengan pihak luar seperti Lembaga Kursus dan Pelatihan (LKP), Balai Latihan Kerja (BLK) saat mereka melakukan uji kompetensi di SMA Negeri 1 Imogiri.

3) Sumber Daya Fasilitas

Pihak SMA Negeri 1 Imogiri telah menyediakan fasilitas yang memadai meliputi 3 ruang laboratorium komputer yang semuanya dalam keadaan baik dan sering digunakan, Komputer-komputer yang ada telah dilengkapi dengan software-sofware terbaru, naskah soal uji kompetensi TIK yang dapat digunakan siswa pada saat latihan.

c. Disposisi

Disposisi tercermin dari komitmen sekolah serta kecakapan pelaksana program.

1) Komitmen

Sekolah telah berkomitmen sejak awal program dilaksanakan dan terbukti dari tahun 2009 hingga kini program uji kompetensi TIK masih berjalan dan telah tercatat lebih dari 2000 siswa dan masyarakat umum yang ikut uji kompetensi. Komitmen dalam melaksanakan program uji kompetensi TIK juga termuat dalam visi misi dan tujuan sekolah yaitu memberikan bekal keterampilan dalam bidang TI yang tersertifikasi secara nasional.

2) Kecakapan

Kecakapan pelaksana tercermin dari pelatih uji kompetensi TIK yang merupakan guru-guru yang sudah kompeten dibidangnya, hal ini dibuktikan dengan telah memiliki sertifikat mengajar sesuai dengan yang diperlukan yaitu mengajar dalam bidang TI. Selain itu juga pada saatmengajar latihan uji kompetensi pada saat mejelaskan materi mudah dipahami oleh sisiwa.

d. Struktur Birokrasi

Struktur birokrasi uji kompetensi TIK di SMA Negeri 1 Imogiri berada dibawah tanggungjawab kepala sekolah. Kepala sekolah sebagai penanggung jawab pelaksanaan program. Struktur birokrasi ini juga terdapat ketua tim dan pelatih. bagian kesiswaan sebagai ketua tim pelaksana yang bertugas mengkoordinasikan program dan juga pelaksana program. Kemudian untuk pelatihnya sekolah telah menunjuk guruguru yang kompeten dalam bidang TI untuk menjadi pengajar atau pengampu pada saat latihan, dengan mempertimbangkan kompetensi mereka yang dibuktikan juga dengan memiliki sertifikat kompeten dalam mengajar. Pelatih atau pengampu latihan bertugas mengatur segala hal teknis dilapangan seperti materi latihan.

\section{Faktor Pendukung dan Faktor Penghambat Implementasi Program Uji Kompetensi TIK di SMA Negeri 1 Imogiri}

a. Faktor Pendukung

Faktor pendukung program uji kompetensi TIK adalah fasilitas yang memadai berupa 3 ruang laboratorium komputer yang semuanya dalam keadaan baik, dukungan penuh dari semua elemen sekolah sehingga untuk kebutuhan pelaksaanaan program tersebut terpenuhi dukungan ini dapat dilihat dari sekolah yang telah berupaya menyediakan sumberdaya yang tepat dengan memilih pelatih yang sudah kompeten yang dibuktikan dengan sertifikat kompetensi dalam bidang TI yang dimiliki, Pendanaan dari pemerintah melalui Bantuan Operasional Sekolah (BOS) dan Bantuan Operasional Sekolah Daerah (BOSDA), Kerjasama Sekolah dengan pihak luar kerjasama dijalin sekolah dengan beberapa lembaga seperti dengan Lembaga Sertifikasi Komputer yang menerbitkan sertifikat bagi siswa yang nanti lulus uji kompetensi, kemudian ada dari Dinas Pendidikan khususnya pendidikan non formal.

b. Faktor Penghambat

Faktor penghambat program uji kompetensi TIK adalah terbatasnya waktu pelatihan yang hanya seminggu sekali dan dilakukan setelah pulang sekolah, latar belakang siswa yang berbeda sehingga siswa juga memiliki karakter yang berbeda, hal ini terlihat dari perilaku yang siswa lakukan saat pelatihan uji kompetensi disekolah ada beberapa siswa yang tidak antusias dengan adanya program ini bahkan ada yang menyepelekan saat latihan 
berlangsung.

\section{SIMPULAN DAN SARAN \\ Simpulan}

Komunikasi dilakukan kepada pelaksana, orang tua siswa dan juga siswa. Komunikasi dengan pelaksana program dilakukan sekolah

Wakil kepala sekolah dengan melakukan sosialisasi kepada staf manajemen, tenaga pendidik, tenaga kependidikan, dan para stakeholder terkait program uji kompetensi TIK dengan mengadakan rapat.

Komunikasi dengan orang tua dilakukan oleh sekolah terkait dengan program uji kompetensi TIK, disampaikan melalui kegiatan sosialisasi secara langsung saat penerimaan peserta didik baru (PPDB) serta menjelang tahun ajaran baru. Komunikasi juga disampaikan kepada siswa melalui sosialisasi program pada saat upacara bendera yang dilakukan disekolah.

Selain berkomunikasi secara langsung, sekolah juga memanfaatkan media cetak maupun media sosial untuk mengkomunikasikan program uji kompetensi TIK, yaitu dengan menggunakan brosur dan web sekolah. Sumber daya yang dimiliki SMA Negeri 1 Imogiri dalam melaksankan program uji kompetensi TIK meliputi sumber daya manusia, sumber pendanaan dan sumber daya fasilitas dalam melaksanakan program uji kompetensi TIK. Sumber daya manusia yang meliputi penanggung jawab, ketua, dan pelatih, selain itu sekolah juga melakukan kerjasama dengan berbagai lembaga, sumber daya pendanaan meliputi Bantuan Operasional Sekolah (BOS), Bantuan Operasional Sekolah Daerah (BOSDA), sumberdaya fasilitas yang dimiliki SMA Negeri 1 Imogiri untuk program uji kompetensi adalah 3 ruan laboratorium komputer dan naskah soal untuk latihan siswa. Para implementator program uji kompetensi TIK sangat mendukung dan berkomitmen melaksanakan kewajibanya semaksimal mungkin sesuai dengan tanggungjawabnya yang telah diamanhkan sejak awal. Struktur birokrasi di SMA Negeri 1 Imogiri berkaitan dengan program uji kompetensi TIK berada dibawah tanggungjawab kepala sekolah.

Faktor pendukung implementasi program uji kompetensi TIK di SMA Negeri 1 Imogiri terdiri dari faktor internal yaitu fasilitas yang memadai serta dukungan penuh sekolah terhadap program. Sementara faktor eksternal yaitu adanya dana dari Pemerintah serta kerjasama sekolah dengan pihak luar. Faktor penghambat implementasi program uji kompetensi TIK di SMA Negeri 1 Imogiri terdiri dari faktor internal yaitu waktu pelatihan yang kurang. Sementara faktor eksternal yaitu latar belakang siswa yang berbeda Saran

1. SMA Negeri 1 Imogiri perlu melakukan koordinasi dengan pihak kurikulum sekolah untuk menambah alokasi waktu untuk latihan uji kompetensi TIK. Hal ini perlu dilakukan karena keterbatasan waktu dan juga terlalu sore waktu untuk latihan uji kompetensi TIK sehingga siswa sudah lelah.

2. SMA Negeri 1 Imogiri perlu memberikan motivasi kepada siswa untuk bersungguh- sungguh dalam mengikuti uji kompetensi TIK atau jika perlu dibuat kontrak antara siswa dan sekolah yang menyatakan bahwa siswa akan bersungguhsungguh dalam latihan ataupun dalam mempersiapkan diri untuk mengikuti uji kompetensi TIK.

\section{DAFTAR PUSTAKA}

Anwar. (2006). Pendidikan Kecakapan Hidup.

Bandung: Alfabeta Bandung.

Arif. Rohman. (2012). Kebijakan Pendidikan (Analisis Dinamika Formulasi dan Implementasi. Yogyakarta: Aswaja Pressindo.

Cintra larasati. 2018. Biaya Masih Jadi

Kendala Melanjutkan Kuliah.

Diakses melalui

https://www.medcom.id/pendidikan/ ne ws-pendidikan/0k8YXggK- 
$\underline{\text { melanjutkan- kuliah }}$

Fauzi Eka Putra. 2017. Kompetensi Komunikasi Pustakawan di Perpustakaan Universitas Islam Negeri Sumatera Utara Medan. Jurnal Iqra' Vol.11 No.2

Miles, Huberman dan Saldana. (2014). Qualitative Data Analyzis. California: Sage Publication

Peraturan Menteri Nomor 22 tahun 2006 tentang Standar Isi

Peraturan Pemerintah No. 19 Tahun 2005 tentang Standar Nasional Pendidikan.

Pusat Teknologi Informasi ( PTI ) Komunita Widyatama. 2019. Memaknai Angka Partisipasi Kasar Pendidikan Tinggi. diakses melalui https://komunita.widyatama.ac.id/ $\underline{\text { mem aknai-angka-partisipasi- }}$ kasar- pendidikan-tinggi/

Sudjana. (2004). Manajemen Program Pendidikan. Bandung: Falah Production.

Suharsimi Arikunto, Cepi Safruddin Abdul Jabar . (2004). Evaluasi Program Pendidikan. Jakarta: PT. Bumi Aksara

Undang-undang No. 20 Tahun 2003 tentang Sistem Pendidikan Nasional

Sulistiyono, T. (2013). Ilmu Pendidikan. Yogyakarta: UNY Press.

Widjanarko, M., \& Minnafiah, U. (2018). Pengaruh Pendidikan Bencana Pada Perilaku Kesiapsiagaan Siswa. Jurnal Ecopsy, 1-7.

Ditjen Pendidikan Dasar dan Menengah. (2017). Peraturan Menteri Pendidikan dan Kebudayaan Nomor 23 Tahun 2017 tentang Hari Sekolah. Jakarta: Depdikbud

Polres Bantul DIY. (2017). 20 Siswa SD ketangkap basah merokok di sekolah.

Diaksesdariwww.tribatanewsbantul .com/2017/01/20-siswa-sdketangkap-basah-merokok-di.html. Pada tanggal 18 Maret 2019, jam $16: 21$ 